DOI 10.18699/SBB-2020-79

\title{
Генетическое сходство Gyrodactylus sphinx (Platyhelminthes: Monogenea) \\ из Черного моря с новым подродом морских видов, обитающих в юго-восточной части Тихого океана, а также в Средиземном и Северном морях
}

\author{
Прохорова Д.А., Дмитриева Е.В., Водясова Е.А. \\ Институт биологии южных морей им. А.О. Ковалевского, Севастополь, Россия
}

Ключевые слова: Gyrodactylus, генетическая изменчивость, Черное море

Моногенеи рода Gyrodactylus von Nordmann, 1832 известны уже почти 200 лет и являются интересными объектами благодаря своему необычному циклу размножения и высокой скорости дивергенции. Представители данного рода распространены практически повсеместно, однако история их расселения и процессы видообразования до сих пор являются предметом дискуссий. Черноморский регион является молодым бассейном с хорошо изученной палеогеографией. Существующая изоляция от Средиземноморья за счет систем проливов Босфор и Дарданеллы, достаточно хорошая изученность видов рыб и время их проникновения в Черное море делает данный регион интересным с точки зрения анализа возможной генетической дивергенции и изучения процессов видообразования рода Gyrodactylus.

В качестве молекулярного маркера был выбран ядерный регион ДНК рибосомального кластера, включающий ITS1, 5.8S, ITS2. Данный маркер является достаточным для того, чтобы говорить о видовой принадлежности, в силу своей консервативности внутри вида.

Проведенный филогенетический анализ показал, что монофилетическая клада Gyrodactylus sphinx сгруппировалась с двумя другими кладами, включая G. orecchiae, G. chileani, G. proterorhini и G. cf. niger, которые ранее были признаны новой группой морских видов, предки которых, вероятно, пересекли экватор. Кроме того, морфология G. sphinx весьма схожа с G. chileani, и оба вида поражают прибрежных морских рыб подотряда Blennioidei. Это говорит об их возможном родстве, несмотря на очень удаленный ареал распространения этих видов.

Благодарности: Работа выполнена в рамках тем № AАAА-А19-119060690014-5 и № AAАA-A18118020890074-2 государственного задания ФИЦ ИнБЮМ.

Список литературы

1. Ziętara MS, Huyse T, Lumme J \& Volckaert FA. 2002. Deep divergence among subgenera of Gyrodactylus inferred from rDNA ITS region. Parasitol. 124:39-52.

2. Ziętara MS, Lebedeva D, Muñoz G \& Lumme J. 2012. A monogenean fish parasite, Gyrodactylus chileani n. sp., belonging to a novel marine species lineage found in the South-Eastern Pacific and the Mediterranean and North Seas. Systematic Parasitol. 83:59-67. 